\title{
PHYSIOCHEMICAL ANALYSIS OF COMMUNITY WATER SUPPLY IN KATHMANDU VALLEY
}

\author{
Dinesh Shah"1
}

\begin{abstract}
This study was carried out to assess groundwater quality of the Kathmandu Valley, Nepal, because Safe drinking water is a basic need of all humans and to protect the human health, community water suppl y must be reliable, adequate and readily accessible to all segments of the consumers. For this the groundwater samples from eight different regions of the valley were collected during months of Jun-Jul in the year 2018. Th ese collected groundwater samples were analyzed various physiochemical parameters such as temperature, colour, turbidity, $\mathrm{pH}$, electric conductivity (EC), total alkalinity, phenolphthalein alkalinity, total hardness, iron, chloride,Nitrate and total ammonia using the procedure outlined in the standard methods. Results showed that the water quality status was found to vary from place to place. High levels of turbidity, total alkalinity, total hardness, iron and total ammonia were found in the groundwater of many sites. The results were compared with WHO water quality guideline and National Drinking Water Qualit y Standard (NDWQS) of Nepal.
\end{abstract}

Keywords : Groundwater, Physio-chemical parameters, community water supply, pH, electrical conductivity

\section{Introduction}

The qualit y of water is of vital concern for mankind, since it is directly linked with human welfare. The faecal pollution of drinking water causes water born disease. Safe drinking water is the basic need of all living beings. To protect the human health, community water supply must be reliable, adequate and readily accessible to all segments of the consumers [5-8].

For drinking Water, it is essential to determine odour, colour, turbidity, $\mathrm{pH}$, total dissolved solids, presence of ammonia, Hardness, iron, Fluoride, free chlorine etc. A number of diseases may be transmitted by water such as typhoid, cholera etc. usuall y, water sources during rainy season changes its path slightly and there might be fluctuation in the above mentioned parameters [9-12].

The measurement of quality of water is a tedious process and a large number of quantitative analytical methods are used. Some chemical analysis of the drinking water suppl y in Kathmandu such as temperature, $\mathrm{pH}$, total hardness, total alkalinity, carbon dioxide, iron, chlorides and ammonia would be considered for stud y using $\mathrm{pH}$ meter, titration and colorimetric anal ysis. This stud y assesses the current status of groundwater quality in the valley and evaluates its suitability for drinking with respect to National Drinking Water Quality Standard (NDWQS) of Nepal and WHO guideli nes [13-17].

1 Assistant Professor, Department of Applied Science,IOE, Thapathali Campus, Tribhuvan University, Thapathali, Kathmandu

Corresponding author

E-mail :dineshshah@tcioe.edu.np 


\section{Materials and Methods}

\section{Groundwater Sampling}

This research was conducted to anal yze drinking water quality of Kathmandu valley. Total 8 water samples received from different places of Kathmandu, and Lalitpur districts during jun and july 2018.The sampling locations and sources of groundwater is given in table 1.The samples were collected in sampling bottles from each site under stud y and then these sampling bottles were labeled with the sample code number. The collected samples were preserved immediately by acidif ying with $2 \mathrm{ml} / \mathrm{L}$ concentrated nitric acid (HNO3) as described in APHA-AWWA-WPCF [18]. All water samples were stored in sterilized bottles and delivered on the same day to laboratory. All the samples were kept at $4^{\circ} \mathrm{C}$ until processing and analysis. These samples were analyzed for the determination of ph ysical ( $\mathrm{pH}$, temperature, conductivit $\mathrm{y}$, turbidity) and chemical (hardness, chloride, iron, arsenic, ammonia, nitrate) parameters.

\begin{tabular}{|c|c|c|}
\hline sample code & Study Sites & Sources \\
\hline WS-1 & Kalanki & Hand pump \\
\hline WS-2 & Lagankhel & Hand pump \\
\hline WS-3 & Pulchowk & Hand pump \\
\hline WS-4 & Chabhil & Hand pump \\
\hline WS-5 & kirtipur & Hand pump \\
\hline WS-6 & Thpathali & Hand pump \\
\hline
\end{tabular}

Table 2: Test parameters, methods of analyses and instruments used

\section{Water quality analysis :}

Altogether 6 drinking water samples were collected and tested in the laboratory of Nepal Academy of Science and Techn ology, Khumaltar, Lalitpur (NAS T ), Department of Food Technology and Qualit y Control, Babarmahal, Ktm, (DFTQC) and Info Lab. Baneswor while Temperature and $\mathrm{pH}$ of water samples were recorded at the site during sampling period. The Physicochemical quality of the water samples tested are given in table2 followed by American Public Health Association[19-21]. Test parameters, methods of analysis and instruments used for analysis are shown in Table 2 below.

\begin{tabular}{cccc} 
S. No. & Parameter & unit & Equipments/Methods \\
\hline 1 & Temperature & celsius & Mercur $y$ Thermometer \\
\hline 2 & $\mathrm{pH}$ & - & $\mathrm{pH}$ meter \\
\hline 3 & Turbidity & $\mathrm{NTU}$ & Turbidimeter \\
\hline 3 & Conductivit y & $\mu \mathrm{s} / \mathrm{cm}$ & Conductivity meter \\
\hline 4 & Iron & $\mathrm{mg} / 1$ & Spectrophotometer \\
\hline 5 & Total Hardness & $\mathrm{mg} / 1$ & EDTA method \\
\hline 6 & Total Alkalinit y & $\mathrm{mg} / 1$ & Titration method \\
\hline 7 & Chloride & $\mathrm{mg} / 1$ & Titration method \\
\hline 8 & Nitrate & $\mathrm{mg} / 1$ & Spectrophotometer \\
\hline 9 & Ammonia & $\mathrm{mg} / 1$ & Spectrophotometer \\
\hline
\end{tabular}

Table 1: Samples from Kathmandu valley 


\section{Results and Discussion}

This research was conducted to anal yze drinking water quality of Kathmandu valley for this total 8 water samples received from different places of Kathmandu,and Lalitpur districts during jun and july 2018. As the most of local people around Kathmandu valley use groundwater for drinking and other domestic purposes hence this study help them to know about water qualit y they are using within the permissible parameters or not.

A comparative study of different water sources was carried out by taking certain important parameters like ph ysical ( $\mathrm{pH}$, temperature, conductivit $\mathrm{y}$, and turbidity), chemical (hardness, chloride, iron, ammonia, nitrate) parameters. The physical parameters i.e. temperature, $\mathrm{pH}$, turbidity and conductivity have been considered as a non- health related factors. The water quality parameters' values and elemental concentration of water samples which are collected from eight different sampling areas are presented in table 2. These results are then compared with value for drinking water as mentioned in the WHO guideline and National Drinking Water Quality Standard (NDWQS) of Nepal. Which shows except temperature all the physical parameters and except nitrate all the chemical parameters exceeded the WHO guideline values in different water sources which have been shown in Table 2.

All the tested water samples contained nitrate are within the WHO permissible values. Nitrate can be added to water from industrial effluents, agricultural and domestic wastes. Nitrate itself is not toxic but the effects are hazardous. The reason behind a microbial contamination in drinking water sources may be due to direct discharge of untreated sewage or municipal wastes into surface waters or in open places near to water sources. The Fe content of the groundwater samples exceeded the NDWQS as well as WHO guideline value for drinking water $[22,23]$. The level Fe level was found maximum in WS-1 which ma y be due to the inflow of surface run off from hill torrents and agricultural wastes. Besides, the abundantly high concentrations of Fe could be the source of high dissolved iron particularly in the deep groundwater. ${ }^{2}$

${ }^{2} 1$. Jha, T.K., (2010), Chemical analysis of surface drinking water in pokhara, Journal of Alpine Chemistry, Vol. 1, 61-64.

2. Pant, B. R., (2011), Ground water qualit y in the Kathmandu valley of Nepal, Environmental Monitoring and Assessment, Vol. 178(1-4), 477-485.

3. Sharma, S., Bajracharya, R., Sitaula, B.K. and Merg, J., (2005), Water quality in the central Himalaya, Current Science, Vol. 9(5), 782.

4. Shrestha, S., Malla, S. S., Aihara, Y., Kondo, N. and Nishida, K., (2013), Water qualit y at supply source and point of use in the Katmandu valley, Journal of water and Environmental Technology, Vol 11(4), 331-340.

5. Sorlini, S., Rondi L., Gomez, A. P., and Collivignarelli, C., (2015), Appropriate technologies for drinking water treatment in mediterranean countries, Environmental Engineering and Management Journal, Vol.14 (7), 1721-1733.

6. World Health Organization (WHO), (2011), Guidelines for drinking water quality, $4^{\text {th }}$ Edition.

7. $A D B$ (2004) Water for all: The impact of water on the poor, Asian Development Bank, Manila.

8. APHA., 1998: Standard methods for the examination of water and waste water. 20 edition, American Public Health Association, Washington D.C. 1-47 pp.

9. $\quad$ Bittner A., Halsey T., Khayyat A., Luu K., Maag B., Sagara J., and Wolfe A., (2000), "Drinking Water Quality and Point - of - use Treatment Studies in Nepal” Pandey B., (2009),

10. Pandey B., (2009), “A Case Study of Drinking Water Quality Status in Central Development Region, Nepal” 
The iron release mechanism is not understood fully, but may be due to the reducing environment, in which iron oxides generally dissolve into soluble form.

The results clearly showed the deteriorating conditions of water quality of Kathmandu valley. Thus the appropriate treatment approaches should be undertaken depending on the defects, in order to make water potable and rules and regulations of environment protection should be strictly adopted to conserve groundwater resources and to protect these sources from contamination.

\begin{tabular}{|c|c|c|c|c|c|c|c|c|c|}
\hline Parameters & Unit & WS-1 & WS-2 & WS-3 & WS-4 & WS-5 & WS-6 & WHO & NDWQS \\
\hline Temperature & $0 \mathrm{C}$ & 26 & 23 & 25 & 24 & 23 & 26 & - & - \\
\hline $\mathrm{pH}$ & - & 6.9 & 7.3 & 6.7 & 7.5 & 6.8 & 6.5 & $6.5-8.5$ & $6.5-8.5$ \\
\hline TDS & $\mathrm{mg} / \mathrm{L}$ & 70 & 45 & 50 & 30 & 10 & 25 & 600 & 1000 \\
\hline Conductivit y & $\mu \mathrm{S} / \mathrm{cm}$ & 1040 & 950 & 1015 & 970 & 325 & 450 & $800-1000$ & 1500 \\
\hline T. Alkalinit y & $\mathrm{mg} / \mathrm{L}$ & 360 & 430 & 150 & 540 & 130 & 520 & - & 200 \\
\hline Chloride & $\mathrm{mg} / \mathrm{L}$ & 11.52 & 8.72 & 6.45 & 9.34 & 5.34 & 7.12 & 250 & 250 \\
\hline T. hardness & $\mathrm{mg} / \mathrm{L}$ & 534 & 650 & 650 & 754 & 213 & 543 & 200 & 500 \\
\hline Ammonia & $\mathrm{mg} / \mathrm{L}$ & 65 & 20 & 35 & 16 & 10 & 25 & 1.5 & 1.5 \\
\hline Nitrate & $\mathrm{mg} / \mathrm{L}$ & 5.04 & 11.56 & 16.75 & 7.3 & 4.3 & 19.6 & 10 & 50 \\
\hline Iron & $\mathrm{mg} / \mathrm{L}$ & 1.8 & 0.3 & 0.4 & 0.2 & 0.3 & 0.8 & 0.3 & 0.3 \\
\hline
\end{tabular}

Table 3: Values of different parameters of water samples

\section{Conclusion}

From this stud y, it can be concluded that the status of groundwater of Kathmandu metropolitan city varies from place to place. It is found that the groundwater in these study sites contains high levels of turbidity, total alkalinity, total hardness and total ammonia which may be due to waste water of agricultural land and other domestic wastes of urban areas. Besides, cleaning kitchen utensils and bathing activities at or around the source ground water are also among the major sources responsible for water quality deterioration. Awareness should be created to public for either using disinfectants or boiling water before use rather than rel y on the belief of purit y. Otherwise, high levels of pollution will greatly influence the population and will invite socio-economic disasters. This study I hope may be considered for future planning in using the groundwater for drinking and other purposes.

\section{Acknowledgment}

I am truly indebted to Prof. Dr. Kedar Ghimire and Assoc. Prof. Dr. Hem Raj Pant f o $r$ their supervision, guidance and invaluable suggestion for the successful completion of this study. I would also like to express my gratitude to Nepal Academy of Science and Technolo g y, Khumaltar, Lalitpur (N A S T ), and Department of Food Technology and Quality Control, Babarmahal, Ktm, (DFTQC) helping for anal yzing the data. I am ver y much thankful to Sabitri Shah,Mr.Takkar B. Shah and Kedar Shrestha for their constant support, co-operation, motivation and ever ready assistance. 